\title{
PEMANFAATAN LIDAH MERTUA (Sansiviera sp) SEBAGAI ADSORBENT Fe, Pb DAN Cr PADA LIMBAH BATIK
}

\author{
Harianingsih $^{1 *}$ dan Farikha Maharani ${ }^{2}$ \\ ${ }^{1}$ Jurusan Teknik Kimia, Fakultas Teknik, Universitas Negeri Semarang \\ Kampus Sekaran, Gunungpati, Semarang \\ ${ }^{2}$ Jurusan Teknik Kimia, Fakultas Teknik, Universitas Wahid Hasyim \\ Jl. Menoreh Tengah X/22 Sampangan Semarang \\ *Email : harianingsih@mail.unnes.ac.id
}

\begin{abstract}
Abstrak
Limbah batik mempunyai sifat karsinogenik karena pewarna sintetik yang digunakan masih banyak mengandung logam berat. Pencemaran oleh logam berat ini antara lain $\mathrm{Fe}, \mathrm{Pb}, \mathrm{Cr}$ mengakibatkan kerusakan lingkungan serta berbahaya untuk kesehatan. Dari permasalahan tersebut penelitian ini dilakukan untuk memperoleh solusi mengurangi pencemaran logam berat yang diakibatkan pada pewarnaan batik menggunakan adsorben lidah mertua. Lidah mertua dapat digunakan sebagai adsorbent logam berat karena glikosid mampu mereduksi limbah logam berat. Tanaman lidah mertua merupakan tanaman yang mudah diperoleh sehingga dapat direkomendasikan sebagai bahan baku pembuatan adsorben untuk mengadsorpsi $\mathrm{Fe}, \mathrm{Pb}$ dan $\mathrm{Cr}$ pada limbah batik. Penelitian ini bertujuan untuk mengetahui pengaruh dari waktu kontak dan pH optimum yang diperoleh, dengan indikator penurunan kadar dari logam $\mathrm{Fe}, \mathrm{Pb}$, Cr. Variasi dari waktu kontak pada penelitian ini adalah 30 menit,, 60 menit, 90 menit, 120 menit dan 150 menit dan variasi pH yang digunakan antara lain $p H$ 2,3,4,5, dan 6. Dari penelitian diperoleh hasil bahwa waktu kontak optimum pada 150 menit dengan penurunan kadar logam berat $\mathrm{Fe}$ sebesar 42,17\%, penurunan kadar Pb sebesar 51,01 $\%$ dan penurunan logam $\mathrm{Cr}$ sebesar 45,57\%. PH optimum pada pH 6 diperoleh prosentase penurunan kadar logam berat yaitu $\mathrm{Fe}$ sebesar 43,7\%, Pb sebesar 51,11\% dan $\mathrm{Cr}$ sebesar $47,23 \%$.
\end{abstract}

Kata kunci : batik, lidah mertua, logam berat

\section{PENDAHULUAN}

Tanaman lidah mertua menurut dinas holtikultura merupakan tanaman yang digunakan untuk mempercantik dan memperindah lingkungan dan juga digunakan sebagai tanaman yang digunakan untuk pencegah polusi dan penjerap debu. Tanaman ini mempunyai warna yang menarik sehingga dijadikan rujukan untuk menambah keindahan dari lingkungan. Selain sebagai tanaman hias, lidah mertua ternyata mempunyai senyawa glikosida yang mempunyai kemampuan untuk mereduksi logam berat. Glukosida tersebut dapat mereduksi logam berat seperti $\mathrm{Fe}, \mathrm{Pb}, \mathrm{Cr}$ dan lainnya untuk diubah menjadi asam amino dan asam organik serta gula. (Wediyanto dkk, 2007).

Saat ini dikembangkan industri batik sebagai peningkatan potensi dan budaya bangsa Indonesia. Akan tetapi industri batik ternyata menghasilkan limbah cair yang perlu dicermati dan dipikirkan oleh peengrajin batik, produsen batik, pemerintah dan masyarakat sekitar. Limbah batik hasil dari perajin biasanya tidak digunakan lagi, hanya ditampung kemudian dibuang ke sungai atau pembuangan limbah. Padahal limbah batik apalagi yang menggunakan pewarna sintetik masih mengandung logam berat yang dapat merusak alam sekitar dan mengganggu kesehatan. Proses pada pembuatan batik yang dapat menghasilkan limbah logam berat pada saat penggambaran pola pada kain baik menggunakan canting (tradisional) maupun menggunakan cetakan tembaga yang dilapisi malam, proses pewarnaan kain, serta proses pencucian, proses pemanasan menggunakan air mendidih (Sasongko, 2010).

Pada saat pewarnaan batik digunakan pewarna yang bermacam-macam dan masih mengandung bahan kimia yang bersifat beracun dan masih mengandung berbagai macam logam berat antara lain $\mathrm{Cu}, \mathrm{Co}, \mathrm{Fe}, \mathrm{Cr}, \mathrm{Pb}$ dan Al(Hunger, 2003). Logam berat yang terikut di dalam pembuangan limbah batik jika masih sesuai dengan kategori aman atau sesuai ambang batas lingkungan tentu saja tidak jadi masalah, akan tetapi jika melebihi ambang batas keamanan lingkungan harus dilakukan pengolahan untuk meminimalisir logam berat yang terikut. Kadar logam berat yang terdapat 
pada limbah batik secara umum untuk tembaga sebesar 0,173 ppm, besi 0,9 ppm, Chrom 0,4 ppm. Peraturan Pemerintah dengan Nomor 72 tahun 2013 mengenai baku mutu air limbah untuk industri menyebutkan bahwasanya kadar logam berat yang seharusnya terbawa ke air lingkungan adalah tidak lebih dari $0,1 \mathrm{ppm}$. Limbah logam berat perlu ada pengawasan dan penanganan terkait logam berat yang terdapat pada limbah batik (Kurnia dkk, 2016).

Dari permasalahan penanganan reduksi beberapa cara antara lain purifikasi limbah cair. Purifikasi limbah cair dapat berupa absorpsi, evaporasi, pertukaran ion, ekstraksi menggunakan pelarur, dan reverse osmosis (Etana, 2004). Pada penelitian ini digunakan metode absorpsi dengan harapan agar logam berat terlarut yang ada dalam limbah cair dapat berkurang. Penelitian ini menggunakan adsorben dari tanaman lidah mertua yang juga mempunyai senyawa glikosida sehingga dapat merubah logam berat menjadi senyawa lain yang tidak beracun dan aman untuk lingkungan sekitar.(Andres dan Ali, 2004). Faktor yang berpengaruh terhadap proses adsorpsi adalah krakteristik adsorben, $\mathrm{pH}$ larutan, temperatur dan waktu kontak. Kinerja dan daya tahan adsorben saat menyerap logam berat dapat diketahui dengan mengukur waktu kontaknya (Asip dkk., 2008). Waktu kontak yang digunakan pada penelitian Sembiring dan Sinaga antara lain 20, 30, 40, 50, 60 menit kemudian didiamkan selama 15 menit. Waktu kontak penting karena dimaksudkan untuk memberikan kesempatan kepada partikel dari adsorbent lidah mertua untuk dapat bersinggungan dengan senyawa yang diserap yaitu logam berat $\mathrm{Fe}, \mathrm{Pb}$ dan $\mathrm{Cr}$ (Sembiring dan Sinaga, 2003).

Tujuan dari penelitian ini untuk mengetahui sejauhmana lidah mertua dapat dimanfaatkan sebagai adsorbent logam berat dengan menganalisis pengaruh faktor waktu kontak dan $\mathrm{pH}$ terhadap penurunan logam berat $\mathrm{Pb}, \mathrm{Fe}$ dan $\mathrm{Cr}$.

\section{METODOLOGI Bahan}

Limbah cair dari Industri batik Gunung Pati Semarang, lidah mertua, Aquades, $\mathrm{NaOH}$, isopropil alkohol, $\mathrm{HNO}_{3}$.

Alat

Alat yang digunakan antara lain alat pecah belah laboratorium, neraca digital, ayakan 100 mesh, kertas saring, oven, $\mathrm{pH}$ meter, magnetic stirer, spektrofotometer serapan atom

\section{Prosedur Kerja \\ Pembuatan Adsorben Lidah Mertua}

Adsorben lidah mertua dibuat dengan cara lidah mertua dicuci dengan air sampai bersih kemudian dipotong dadu dengan ukuran $1 \mathrm{~cm} \mathrm{x}$ $1 \mathrm{~cm}$. Potongan lidah mertua direndam dengan larutan isopropil alkohol dengan lama waktu perendaman 24 jam. Setelah direndam dengan isopropil alkohol, lidah mertua dicuci kembali menggunakan aquades dan dikeringkan selama 24 jam menggunakan oven. Lidah mertua yang telah kering dicampur dengan larutan $\mathrm{NaOh}$ $3 \%$. Kemudian dilakukan pencucian lagi menggunakan aquades dan dilanjutkan pencucian menggunakan $\mathrm{HNO}_{3} \quad 0,01 \mathrm{M}$. Langkah selanjutnya adalah pengeringan pada suhu $100{ }^{\circ} \mathrm{C}$ menggunakan oven dalam waktu 24 jam.

\section{Karakterisasi Adsorben Lidah Mertua}

Bahan yang digunakan sebagai adsorben harus sesuai dengan baku mutu yang ada di SNI dengan Nomor 06.3730.1995 tentang baku mutu adsorben meliputi rendemen adsorbent yang terbentuk, kadar air adsorbent, kadar abu adsorbent, daya serap iodium adsorbent. Persamaan yang digunakan untuk menentukan besar rendemen antara lain :

Rendemen $=\underline{\text { massa adsorben setelah dikeringkan }} \times 100 \% \ldots \ldots 1)$ Massa lidah mertua mula-mula

\section{Analisis Kadar Air}

5 gram lidah mertua yang dudah dikeringkan diletakkan dalam cawan porselen, kemudian dipanaskan dalam oven pada suhu $105^{\circ} \mathrm{C}$ dalam waktu 6 jam. Hasil pengeringan kemudian diletakkan dalam desikator. Untuk menentukan kadar air digunakan persamaan sebagai berikut

$\%$ kadar air $=\frac{\mathrm{A} 1-\mathrm{A} 2}{\mathrm{~A}} \times 100 \%$

Keterangan :

A : berat lidah mertua mula-mula $(\mathrm{g})$

A1 : berat lidah mertua + cawan sebelum dikeringkan

A2 : berat lidah mertua + cawan setelah dikeringkan

\section{Analisis Kadar Abu}


Sebanyak 5 gram adsorben lidah mertua diletakkan dalam cawan porselen kemudian dipanaskan dalam suhu $105^{\circ} \mathrm{C}$ pada oven dalam kurun waktu 9 jam. Lidah mertua yang sudah kering dibakar dalam furnace $600^{\circ} \mathrm{C}$ dalam waktu 180 menit. Hasil pembakaran pada furnace kemudian ditimbang. Untuk menentukan kadar abu digunakan persamaan sebagai berikut :

\% Kadar Abu : Berat abu (g) x 100\%............3) Berat lidah mertua $(\mathrm{g})$

\section{Pengaruh Waktu Kontak Terhadap Penurunan Kadar Logam Berat}

Adsorben lidah mertua hasil dari pengeringan ditimbang sebanyak 10 gram, dilarutkan ke dalam $200 \mathrm{ml}$ larutan limbah batik yang berasal dari pengrajin batik di Gunungpati Semarang. Adsorben lidah mertua dikontakkan dengan larutan limbah batik dengan variasi waktu kontak 30 menit, 60menit, 90menit, 120menit dan 150 menit. Campuran diputar menggunakan magnetik stirer dalam waktu 30 menit dengan percepatan putara $200 \mathrm{rpm}$. Larutan adsorbent disaring menggunakan penyaring vakum kemudian filtrat hasil saringan diukur kadar logam beratnya $(\mathrm{Fe}, \mathrm{Pb}$ dan Chrom) menggunakan spektrofotometer AAS.

\section{Pengaruh pH Terhadap Penurunan Kadar Logam Berat}

Adsorben lidah mertua yang telah jadi ditimbang dengan massa 10 gram, kemudian dilarutkan dalam larutan limbah batik $200 \mathrm{ml}$ dengan ditambahkan $\mathrm{NaOH}$ sehingga larutan batik mempunyai variasi $\mathrm{pH}$ 2,3,4,5,6. Kemudian diputar menggunakan magnetik stirer selama 30 menit dengan kecepatan putaran $200 \mathrm{rpm}$. Setelah itu disaring dan filtrat diukur kadar logam beratnya menggunakan spektrofotometer serapan atom.

\section{HASIL DAN PEMBAHASAN}

\section{Karakterisasi Adsorben Lidah Mertua}

Hasil uji kualitas adsorben secara rinci disajikan pada tabel 1 .

Tabel 1. Standar Baku Adsorben

\begin{tabular}{|c|c|c|}
\hline Parameter & Standar Mutu & Hasil \\
\hline & $\begin{array}{ll}\text { SNI } & \text { No. } \\
\text { 06.3730.1995 }\end{array}$ & Analisis \\
\hline Rendemen & - & $83 \%$ \\
\hline
\end{tabular}

\begin{tabular}{|c|c|c|c|}
\hline Kadar Air & $\begin{array}{l}\text { maksimum } \\
15 \%\end{array}$ & & $9 \%$ \\
\hline Kadar Abu & $\begin{array}{l}\text { maksimum } \\
10 \%\end{array}$ & & $5 \%$ \\
\hline $\begin{array}{l}\text { Daya Serap } \\
\text { Iodium }\end{array}$ & $\begin{array}{l}\text { minimal } \\
\mathrm{mg} / \mathrm{g}\end{array}$ & 750 & $754,36 \mathrm{mg} / \mathrm{g}$ \\
\hline
\end{tabular}

Berdasarkan hasil analisis standar baku mutu adsorben lidah mertua yang tersaji pada tabel 1, memperlihatkan bahwa kualitas adsorben dari lidah mertua telah memenuhi syarat SNI No. 06.3730.1995, meliputi pengujian jumlah rendemen sebesar $83 \%$, kadar air air di bawah standar SNI juga sebesar 9\%, kadar abu dibawah standar SNI sebesar 5\%, daya serap iodium $754,36 \mathrm{mg} / \mathrm{g}$.

\section{Pengaruh Waktu Kontak Terhadap Kadar Logam Berat}

Pada penelitian yang telah dilakukan, diperoleh data hubungan antara waktu kontak dengan penurunan kadar $\mathrm{Fe}, \mathrm{Pb}, \mathrm{Cr}$.Gambaran data dapat dilihat pada gambar 1 .

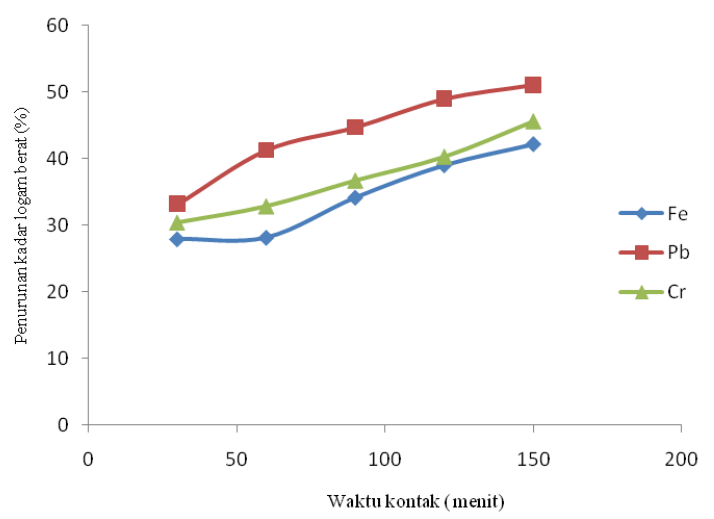

\section{Gambar 1. Grafik pengaruh waktu kontak terhadap penurunan kadar logam berat}

Pada Gambar 1 menunjukkan bahwa optimasi proses yang dilakukan menggunakan variasi waktu kontak 30 menit, 60menit, 90menit,120 menit dan 150 menit dengan mengontakkan adsorben lidah mertua dengan limbah batik yang mengandung logam berat $\mathrm{Fe}$, $\mathrm{Pb}, \mathrm{Cr}$. Semakin lama waktu kontak logam berat yang diserap semakin banyak. Pada waktu kontak 150 menit diperoleh prosentase penurunan kadar Fe sebesar 42,17\%, penurunan kadar $\mathrm{Pb}$ sebesar 51,01 \% dan penurunan logam Cr sebesar 45,57\%. 
Pada kondisi ini adsorben lidah mertua berperan mengadsorbsi logam berat $\mathrm{Fe}, \mathrm{Pb}$ dan $\mathrm{Cr}$, dimana gugus $\mathrm{OH}-$ dari $\mathrm{NaOH}$ berinteraksi secara maksimal dengan ion $\mathrm{Fe}, \mathrm{Pb}$ dan $\mathrm{Cr}$. Hal ini sesuai dengan teori dari Safrianti, dkk ( 2011) yang menyatakan bahwa semakin lama waktu kontak maka ion logam berat yang terserap semakin banyak sehingga prosentase penurunan kadar logam berat lebih besar.

Proses adsorpsi juga dipengaruhi oleh $\mathrm{pH}$ proses penyerapan oleh lidah mertua dan logam berat. Hal ini dapat dilihat pada gambar 2.

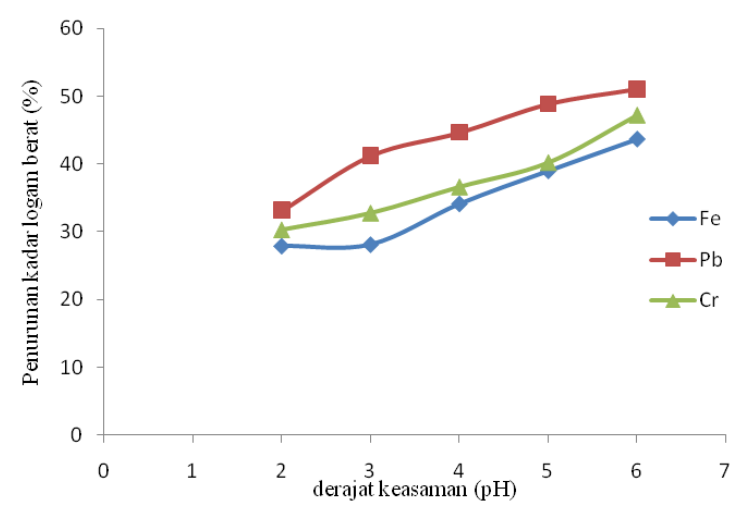

\section{Gambar 2. Grafik Pengaruh pH terhadap prosentase penurunan kadar logam berat $(\%)$}

Grafik pengaruh $\mathrm{pH}$ terhadap prosentase penurunan kadar logam memperlihatkan bahwa semakin tinggi $\mathrm{pH}$ maka semakin besar juga penurunan kadar logam berat. $\mathrm{pH}$ mempengaruhi gugus-gugus fungsional dari dinding biomassa yang berperan aktif dalam penyerapan logam berat. Pada $\mathrm{pH} 6$ diperoleh prosentase penurunan kadar logam berat yaitu $\mathrm{Fe}$ sebesar $43,7 \%, \mathrm{~Pb}$ sebesar $51,11 \%$ dan $\mathrm{Cr}$ sebesar $47,23 \%$. Penurunan kadar logam berat ini sesuai dengan penelitian yang dilakukan oleh Baidho dkk (2013) yang menyebutkan bahwa kapasitas adsorbsi cenderung rendah $\mathrm{pH}$ dan tinggi pada $\mathrm{pH}$ tinggi. Pada $\mathrm{pH}$ rendah terjadi kompetisi antara $\mathrm{Fe}^{2+}, \mathrm{Pb}^{2+}$ dan $\mathrm{Cr}^{2+}$ dengan ion $\mathrm{H}^{+}$untuk berikatan dengan permukaan adsorben lidah mertua yang memiliki situs negatif. Sedangkan pada $\mathrm{pH}$ tinggi terjadi endapan $\mathrm{Fe}(\mathrm{OH})_{2}, \mathrm{~Pb}(\mathrm{OH})_{2}$ dan $\mathrm{Cr}(\mathrm{OH})_{2}$.

\section{KESIMPULAN}

Pada penelitian ini diperoleh kesimpulan antara lain : a. Waktu kontak optimum pada 150 menit dengan penurunan kadar logam berat $\mathrm{Fe}$ sebesar 42,17\%, penurunan kadar $\mathrm{Pb}$ sebesar $51,01 \%$ dan penurunan logam $\mathrm{Cr}$ sebesar $45,57 \%$.

b. PH optimum pada pH 6 diperoleh prosentase penurunan kadar logam berat yaitu $\mathrm{Fe}$ sebesar $43,7 \%, \mathrm{~Pb}$ sebesar $51,11 \%$ dan $\mathrm{Cr}$ sebesar $47,23 \%$.

\section{DAFTAR PUSTAKA}

Andreas, dkk., 2004. Penurunan Kadar Besi oleh Media Zeolit Alam Secara Kontinyu. Laporan Penelitian Jurusan Teknik Lingkungan ITS.

Asip, dkk., 2003. Uji efektifitas Cangkang Telur dalam Mengadsorpsi Ion Fe dengan Proses Batch. Jurnal Teknik Kimia, 3(2):15.

Baido, dkk., 2013. Adsorpsi Logam Berat Pb dalam Larutan Menggunakan Senyawa Xanthar Jerami. Prosiding SNST Universitas Wahid Hasyim.

Etana, 2014. Studi Penurunan Kadar Fe pada Limbah Batik dengan Sistem Purifikasi Menggunakan Adsorben Nanopartikel Magnetik. Prosiding Ilmiah HFI.

Hunger, K., 2003. Industryal Dyes. Germany : Wiley.

Kurnia, M., dkk., 2016. Potensi Jerami Sebagai Adsorben Logam Timbal Pada Limbah Cair Batik Sidokare. Jogjakarta : Lentera.

Safrianti, I., Wahyuni, 2012. Adsorbsi Timbal Oleh Selulosa Jerami Padi Teraktivasi Asam Nitrat : Pengaruh $\mathrm{pH}$ dan Waktu Kontak. Jurnal Kimia, 1(1): 1-7.

Sasongko, D., P., 2010. Identifikasi Unsur Kadar Logam Berat Pada Limbah Pewarna Batik dengan Metode Analisis Pengaktifan Neutron. Jurnal Ilmu Pengetahuan dan Teknologi, 2(7):22-27.

Sembiring dan Sinaga, 2003. Arang Aktif: Pengenalan dan Proses Pembuatannya. Laporan Penelitian Teknik Industri . Universitas Sumatera Utara.

Wediyanto, A., 2007. Standar Operasional Prosedur Budidaya Krisan Potong. Direktorat Budidaya Tanaman Hias. Jakarta. 